\title{
Jubileusz Jerzego Szymanka
}

Jubilat urodził się w roku, w którym Stronnictwo postanowiło stanąć na czele rewolucji chłopskiej - Wielkiego Strajku Chłopskiego.

Ten rok był ważnym dla całej jego rodziny. Pisał o tym w swoich wspomnieniach: „Urodziłem się 11 kwietnia 1937 r. we wsi Ręczno w powiecie piotrkowskim w województwie łódzkim. Do tej uroczej, ukrytej w lasach, nad pilickiej miejscowości sprowadzili się rodzice w 1926 r. z sąsiedniej, oddalonej o kilka kilometrów ich rodzinnej wsi, równie uroczej i mającej tak jak Ręczno bogatą historię, Bąkowej Góry. Byłem bardzo oczekiwany - bo męskim potomkiem, po wcześniejszych narodzinach przed kilkunastu laty sióstr: starszej Marii i młodszej Janiny.

Pojawiłem się w rodzinie charakterystycznej wówczas dla tego rejonu typowo patriarchalnej. Ojciec był rzeczywistą, wszechwładną głową, matka wzorem pracowitości, trzymała w ręku cztery węgły domu, siostry przywykły do obowiązków nie tylko szkolnych, ale rozlicznych domowych. Byliśmy rodziną niezwykle pracowitą, prawą, etyczną, zaradną, szanującą innych, ciekawą świata znajdującego się nie tylko za opłatkami. Zresztą taka była przytłaczająca większość mieszkańców Ręczna.

Zasady pomocy innym, wymagania od siebie, współdziałania były w życiu rolników powszechnie obowiązujące. Wychodziły one z wielowiekowych tradycji, wielowiekowej działalności pokoleń, wielu wybitnych osób i aktywnych organizacji. W tę atmosferę znakomicie wrosła znana rodzina”.

Dla Jerzego Szymanka lata najmłodsze to czas wzrastania w niezwykle uspołecznionej, otwartej, przyjaznej ludziom rodzinie. W tej atmosferze był wychowany. Zawsze w niej była prawda i przyzwoitość, wiedziano co to honor i patriotyzm.

Jego osobowość od najmłodszych lat kształtowała się instynktownie.

„Wyrastałem - pisał - w zupełnym oczywistym przekonaniu, że człowiek szczęśliwy to nie egoista myślący tylko o sobie, ale człowiek rozumiejący innych, pomagający ludziom, rozumiejący motywacje ich postępowania, otwarty na świat. Ta wartość zawsze przyświecała wszystkim członkom mojej rodziny. Szczególnie ważne było to w czasie wojny i okupacji”.

Pierwsze lata życia Jerzego Szymanka do wybuchu wojny były szczęśliwe i bezpieczne. Po wybuchu wojny z uwagi na działalność ojca cała rodzina żyła w zagrożeniu. Ojciec wielokrotnie cudem uniknął śmierci. Ręczno było wsią, w której większość dorosłych mieszkańców była w podziemiu. Jako dziecko był świadkiem wielu dramatycznych wydarzeń, akcji bojowych z wieloma poległymi, pacyfikacji i pożarów. Widział śmierć Niemców, partyzantów, 
a potem żołnierzy radzieckich. Była to dla niego trudna lekcja patriotyzmu, poświęcenia dla ojczyzny, hartu.

Okres wojny i okupacji był jego młodzieńczym przeszkoleniem. Cała rodzina zaangażowana była w konspiracji. Ojciec, Piotr Szymanek, był współtwórcą chłopskiego ruchu oporu w powiatach radomszczańskim i piotrkowskim, komendantem powiatowym Ludowej Straży Bezpieczeństwa w powiecie piotrkowskim, Niemcy wielokrotnie próbowali go aresztować. Nie znajdowali Szymanka w domu, terroryzowali jego rodzinę.

Niebezpiecznie było po wyzwoleniu. Piotr Szymanek zaangażował się w odbudowę kraju, był przewodniczącym Powiatowej Rady Narodowej. Wiele wysiłku włożył w nakłanianie swoich partnerów z podziemia akowskiego do ujawnienia, nie wszyscy to uczynili.

Jerzy Szymanek był świadkiem koszmarnego zdarzenia. Było to już po wyzwoleniu. Były dowódca oddziału partyzanckiego AK Stanisław Karliński „Burza”, wraz z czterema swoimi partyzantami na koniach, zorganizowali najazd na dom w Ręcznie.

Rodzina została sterroryzowana i ustawiona do egzekucji pod ścianą domu. Grożono im zabiciem, jeżeli ojciec nie wymusi na NKWD uwolnienia z więzienia jego żony i dzieci aresztowanych przez Rosjan. Okazało się wtedy, że wspólnie przelana krew w walce z Niemcami, wzajemne ratowanie sobie życia, nie miały już znaczenia. Matka Jerzego przypłaciła chwile grozy chorobą, przez rok leżała sparaliżowana i zmarła w wieku czterdziestu trzech lat. W połowie 1945 r. cała rodzina opuściła wieś i przeniosła się do Piotrkowa.

Jego ojciec Piotr aktywnie działał w strukturach wojewódzkich Stronnictwa Ludowego i w 1945 r. został posłem do Krajowej Rady Narodowej, a on rozpoczął edukację szkolną w Piotrkowie.

Naukę rozpoczął od drugiej klasy. Szkołę podstawową ukończył w 1950 r. i rozpoczął naukę w liceum im. Bolesława Chrobrego w wydzielonej klasie, do której przeniesiono 40 najlepszych uczniów intensywnie zdobywających wiedzę. Nauka w szkole to szczególny okres dorastania młodego, zdolnego ucznia, pełnego pasji w działalności młodzieżowej i sportowej. Przez okres nauki był przewodniczącym Zarządu Szkolnego Związku Młodzieży Polskiej. Kierowana przez niego organizacja - za zgodą szkoły - stroniła od polityki na rzecz zespołów samopomocy dla słabszych uczniów, prowadzeniu atrakcyjnych zajęć kulturalnych i rozwijania na wysokim poziomie zajęć sportowych. Grał w siatkówkę i koszykówkę od młodości, poprzez studia i później.

W 1954 r. po ukończeniu Liceum Ogólnokształcącego w Piotrkowie Trybunalskim, jako 17-latek, zdał egzaminy i rozpoczął studia na elitarnym Wydziale Dziennikarskim Uniwersytetu Warszawskiego, a w 1958 r. uzyskał tytuł magistra. Nadal pasjonowała go działalność w ZMP, której był przewodniczącym na Wydziale. Na szczęście na jego naukę i studia nie miały wpływu problemy jego ojca usuniętego w 1951 r. „za odchylenia prawicowe” z szeregów Zjednoczonego Stronnictwa Ludowego i z aktywnego życia politycznego. Po 1956 r. ojciec Jerzego wrócił do łaski, został wybrany prezesem ZW ZSL w Łodzi. W 1957-1959 pełnił funkcję przewodniczącego Prezydium Wojewódzkiej Rady Narodowej 
w Łodzi. W latach 1957-1965 był posłem na Sejm w okręgu piotrkowskim. Ale cały czas nad jego głową gromadziły się chmury.

Ten wybitny działacz ludowy, pragmatyk, demokrata, starający się o wysoki standard pracy Stronnictwa i terenowych organów przedstawicielskich - był zwalczany brudnymi metodami pomówień przez prominentnych działaczy PZPR, wśród których oskarżenia o ciążenie do prawicowego nurtu ZSL, dążenie do przejścia władzy przez Stronnictwo, krytykę polityki rolnej partii i ZSRR - były zdecydowanie najcięższe i zmierzały do ponownej eliminacji z polityki. Były to jednak próby mało skuteczne.

W tym czasie Jerzy Szymanek jako 21-latek rozpoczął dorosłe życie. Miał za sobą doświadczenie w działalności młodzieżowej do 1956 r. w ZMP. Po rozpadzie tej organizacji w 1957 r. organizował ZMW na uczelni.

Pracę zawodową rozpoczął w 1958 r. w Redakcji „Dziennika Ludowego” jako redaktor, a następnie kierownik działu społeczno-politycznego, członek kolegium redakcyjnego, zastępca redaktora naczelnego w latach 1968-1971. Od marca 1966 r. do lipca 1968 r. był zastępcą redaktora naczelnego tygodnika ZMW „Zarzewie”. W obu pismach zajmował się przede wszystkim publicystyką oświatowo-wychowawczą, społeczno-polityczną i sprawozdawczością parlamentarną. Był aktywnym działaczem Stowarzyszenia Dziennikarzy Polskich, członkiem Zarządu Klubu Sprawozdawców Parlamentarnych. Laureat nagrody publicystycznej im. Tomasza Nocznickiego. Był członkiem prezydium Ogólnopolskiego Komitetu Pokoju, członkiem Zarządu Głównego Towarzystwa Przyjaźni Polsko-Radzieckiej.

Od 1959 r. działacz ZSL, prezes koła w Dzienniku Ludowym, wiceprzewodniczący a następnie przewodniczący komisji młodzieżowej Naczelnego Komitetu. W latach 1966-1971 członek Prezydium Zarządu Głównego ZMW i członek Prezydium Rady Naczelnej Ludowych Zespołów Sportowych.

W końcu 1971 r. zakończył się dla Jerzego Szymanka 13-letni okres uprawiania zawodu dziennikarza. Pracował tam z żoną, która była utalentowanym dziennikarzem, redagowała ostatnią kolumnę w „Dzienniku Ludowym” i kolorowy dodatek, który był protoplastą kolorowych magazynów. Ukazywał się w nakładzie 100 tys. egzemplarzy.

Pod koniec 1971 r. zaczął się dla niego nowy okres życia, w którym zawodowe zaangażowanie się w politykę całkowicie go pochłonęło. W ramach odnowy życia politycznego kierownictwa obu partii PZPR i ZSL wysłały w teren swoich nowych, na ogół młodych działaczy, do objęcia kluczowych stanowisk.

Do Łodzi, jednego z największych województw w kraju, na wojewodę powołany został Roman Malinowski, a prezesem Wojewódzkiego Komitetu ZSL został wybrany Jerzy Szymanek. Nie przypuszczał wtedy, że będzie podążał drogą kariery politycznej ojca, że w tej drodze będzie starał się odzyskać rzeczywisty wpływ na wszystko, co się w województwie dzieje. Współpracując z partnerami politycznymi, zachować pełną samodzielność i niezależność. Wypracowywał własny program nie tylko w sferze ekonomiczno-rolnej, ale także społeczno-socjalnej. Zamierzał być rzeczywistym partnerem w rządzeniu województwem. Oddał się bez reszty pracy w terenie, angażując młodych, starych, 
rolników i inteligencję ludową. Praca przyniosła efekty, zrozumienie i uznanie wśród partnerów politycznych, który zmienili swój stosunek do ZSL.

W 1972 r. musiał zmierzyć się z powołaniem samodzielnych, wyposażonych w duże kompetencje i środki gmin kierowanych przez naczelników, zamiast dotychczasowych gromad. Udało się wtedy stworzyć racjonalną, uzasadnioną strukturę jednostek terytorialnych. Dzięki konsekwencji w działaniu i uporowi, w co trzeciej gminie ludowcy pełnili funkcje naczelników.

W tym samym roku zorganizował w Łodzi wielkie spotkanie żołnierzy Batalionów Chłopskich z okazji 30. rocznicy walk BCh na Zamojszczyźnie. Odbyło się w Teatrze Nowym z wręczeniem odznaczeń i wystawionym musicalem pt. „Dziś do Ciebie przyjść nie mogę”. W uzgodnieniu z reżyserem i scenarzystą, uzupełniono przedstawienie o kilka bechowskich piosenek, a występujących z biało-czerwonymi opaskami AK, zmieniono na opaski BCh. Kilkaset żołnierzy BCh otrzymało pełną radość i satysfakcję za ich walkę i poświęcenie dla Ojczyzny.

W 1973 r. pożegnał się z Łodzią. Odbywający się w Warszawie w marcu VI Kongres ZSL wybrał go na sekretarza NK ZSL. Zgodnie ze swoimi predyspozycjami, wykształceniem i doświadczeniem miał zajmować się problemami: oświaty, nauki, kultury, sprawami socjalnymi, problemami polityki historycznej, problemami ochrony zdrowia, rozwoju rodziny i młodzieży.

Była to sfera działania w Stronnictwie bardzo trudna, wymagająca gruntownej wiedzy, zręczności, inwencji. Partnerzy polityczni uważali, że domena, stronnictwa winna być gospodarka żywnościowa. Wiele poświęcał uwagi doskonaleniu systemu edukacji.

W 1975 r. nic nie zapowiadało tragedii rodzinnej. Stało się najgorsze i nieprzewidywane. Piotr Szymanek był silnym mężczyzną, zapalonym myśliwym. Zmarł niespodziewanie 18 sierpnia 1975 r. w Warszawie na skutek ran odniesionych w nieszczęśliwym wypadku podczas polowania. Pogrzeb odbył się na cmentarzu parafialnym w Bąkowej Górze. Była wielką manifestacją patriotyczną i wyrazem hołdu dla niezwykłego chłopa tej ziemi. Była to ogromna strata osobista dla 38-letniego polityka. Jego kariera polityczna i parlamentarna w Warszawie do 1984 r. rozwijała się niezwykle dynamicznie i pomyślnie u boku Stanisława Gucwy, Stefana Ignara i Romana Malinowskiego. Był wysoko ceniony, lubiany w Stronnictwach, w których uosabiał wszystkie cechy prawdziwego ludowca, którego celem było odzyskanie samodzielności przez ruch ludowy. Niestrudzoną pracą, słowem, piórem, energią budził podziw, jak i zazdrość. Nie znamy w pełni przyczyn, które sprawiły, że na IX Kongresie ZSL w 1984 r. nie został wybrany w skład Naczelnego Komitetu ZSL. Był to niewątpliwie przełom w jego karierze politycznej. Ale nie uprzedzajmy faktów w encyklopedycznym skrócie: na VII Kongresie w 1976 r., jak i VIII Kongresie Stronnictwa 15 grudnia 1980 r. został członkiem prezydium i sekretarzem NK. 9 marca 1981 r. na III Plenum NK wybrało go wiceprezesem Stronnictwa. Obowiqzki te petnił do marca 1984 r. W latach 1984-1988 był przewodniczq̨cym komisji prasy i środków masowego przekazu Naczelnego Komitetu. Od marca 1988 od X Kongresu był członkiem 
Naczelnego Komitetu. Od 3 stycznia 1981 r. był członkiem prezydium i sekretarzem Ogólnopolskiego Komitetu FJN.

Od lutego 1972 do listopada 1985 był posłem na Sejm. W VI kadencji Sejmu w latach 1972-1976 był wiceprzewodniczącym klubu poselskiego ZSL, członkiem komisji spraw zagranicznych Sejmu. W VII kadencji Sejmu był wiceprzewodniczącym komisji mandatowo-regulaminowej i przewodniczącym podkomisji do spraw realizacji budżetu i inwestycji w komisji oświaty. Był wiceprzewodniczącym polsko-japońskiej grupy Unii Międzyparlamentarnej. W VIII kadencji Sejmu, po sierpniu 1980 roku, był wiceprzewodniczącym komisji nadzwyczajnej do kontroli realizacji porozumień z Gdańska, Szczecina i Jastrzębia. Pracował w zespole przygotowującym ustawę umożliwiającą rejestrację niezależnych związków zawodowych rolników. Wspierał reaktywowanie Związku Młodzieży Wiejskiej, powstałego 3 grudnia 1980 r. Zarządy gminne i wojewódzkie ZSL wspierały kadrę instruktorską ZMW. W jej siedzibach mieściły się biura organizacyjne organizacji młodzieżowych. Jerzy Szymanek zabiegał, aby ZMW rozwinął działalność na wyższych uczelniach w całym kraju. Komisja Historyczna Zarządu Krajowego ZMW zgromadziła wybitnych badaczy dziejów ruchu młodowiejskiego, której zadaniem było dostarczenie wiedzy potrzebnej do walki o tożsamość ZMW. Kierując Komisją, starał się, aby ideały ZMW RP „Wici” przybliżyć młodemu pokoleniu działaczy ZMW.

Jerzy Szymanek był głównym mówcą w imieniu ZSL na plenarnych posiedzeniach Sejmu w dyskusji nad aktami prawnymi, najpierw 18.12.1982 roku zawieszającymi stan wojenny, a następnie 21.07.1983 r. znoszącymi stan wojenny.

W marcu 1983 r. Sejm wybrał go sekretarzem Rady Państwa. Pełnił tę funkcję do listopada 1985. Był wiceprzewodniczącym Komisji Organów Kontroli.

W latach 1983-1990 był przewodniczącym Towarzystwa Przyjaźni Polsko-Arabskiej. W 1985 r. zakończyła się kadencja Sejmu i Rady Państwa, przestał być sekretarzem i posłem. Postanowił szukać pracy, miał 48 lat i był pełen sił twórczych.

W tym czasie odchodził na emeryturę, jego kolega, wiceprezes „Cepelii” Waldemar Winkiel.

„Cepelia” była ważną strategicznie instytucją, która od 1981 r. z odpisu części zysków za zgodą Ministerstwa Finansów przekazywała środki na działalność ZSL. Stronnictwo i „Cepelia” miały zawartą umowę partnerską o współpracy kulturalnej, promowania „Cepelii” w licznych periodykach prasowych oraz przez struktury Stronnictwa.

Głównym autorem tej koncepcji był Jerzy Szymanek, który jako wiceprezes ZSL w maju 1981 r., po wyborze Stefana Ignara na prezesa Stronnictwa, prowadził negocjacje z PZPR i „Cepelią” w sprawie nowej formuły finansowania ZSL. Ignar nie chciał, aby Stronnictwo otrzymywało pieniądze od partii za pośrednictwem Ministerstwa Spraw Wewnętrznych - asygnowanych z tzw. funduszu specjalnego.

Stronnictwo nie mogło utracić płynności przekazu środków z tego źródła utrzymania. W uzgodnieniu z Waldemarem Winklem postanowił ubiegać się 
o pracę na tym stanowisku. Był znakomicie przygotowany do objęcia tej funkcji. Wiedział o „Cepelii” wszystko.

W 1986 r. został wybrany na stanowisko wiceprezesa zarządu Centralnego Związku Spółdzielni Rękodzieła Ludowego i Artystycznego „Cepelia”, a w 1988 na stanowisko prezesa zarządu. Obowiązki te pełnił do sierpnia 1990 r. Firmę przekazał swojemu wiceprezesowi Janowi Włostowskiemu. Był członkiem prezydium Naczelnej Rady Spółdzielczej, członkiem Rady Społeczno-Gospodarczej przy Sejmie, członkiem Rady Naczelnej Towarzystwa Łączności z Polonią Zagraniczną „Polonia”, założycielem fundacji „Polonia”.

Od 01.02.1991 r. pracował jako dyrektor w firmach informatycznych, najpierw w firmie „Karen International”, potem w P.Z. „Investbau”, następnie w ICD Comp i spółce akcyjnej „Computerland” .

W kwietniu 1995 roku powołany został na stanowisko dyrektora generalnego w Kancelarii Sejmu i szefa gabinetu Marszałka Sejmu. Była to oferta nie do odrzucenia. Jego współpraca z marszałkiem Józefem Zychem była bardzo owocna i ciekawa. Ukoronowaniem jego pracy była do dziś obowiązująca Konstytucja. Józef Zych w książce pt. „Trudna lekcja demokracji” tak pisał: „Skoro wspominam J. Szymanka, to z całą satysfakcją podkreślam, że był to jeden z nielicznych działaczy PSL, w przeszłości wiceprezes ZSL i sekretarz Rady Państwa, mający doskonałe przygotowanie do uprawiania polityki, który potrafił przeprowadzać bezbłędne analizy sytuacji. Dalsze lata bliskiej współpracy z Jerzym przekonały mnie, że ma on wyjątkową i cenną cechę bezwzględnej lojalności. U Szymanka gromadzili się o każdej porze dnia działacze PSL różnych szczebli, aby zachęcać go do rozmów ze mną na temat konieczności kandydowania. Jerzy robił co mógł, łącznie z próbą szukania pomocy u mojego syna Cezarego, który był umiarkowanym zwolennikiem tej propozycji. Mam prawo przypuszczać, że Szymanek, mając dobre rozeznanie szans wyborczych poszczególnych kandydatów, najbardziej przeżył moją odmowę. Na pewno nie chodziło mu o spełnienie osobistych aspiracji, ale o dobrze pojęty interes państwa i Stronnictwa”" ${ }^{\text {. Pracował na }}$ tym stanowisku do listopada 1997. W latach 2004-2005 był doradcą wicemarszałka Sejmu.

Od 2005 r. ponownie podjął pracę jako wiceprezes zarządu w spółce ICD Comp w grupie kapitałowej „Sygnity” i kontynuował ją aż do przejścia na emeryturę.

Jest odznaczony Orderem Sztandaru Pracy II Klasy, Krzyżem Komandorskim i Krzyżem Kawalerskim Orderu Odrodzenia Polski, a także medalami Komisji Edukacji Narodowej (dwukrotnie), odznakami Zasłużony Działacz Kultury, Zasłużony Działacz Kultury Fizycznej, Złotą Honorową Odznaką Towarzystwa „Polonia”, Złotymi Odznakami za Zasługi dla Województw: Warszawskiego, Piotrkowskiego, Nowosądeckiego.

8 kwietnia w Sali Kolumnowej Sejmu RP odbyło się uroczyste spotkanie posłów i senatorów z okazji 20. rocznicy uchwalenia Konstytucji RP w 1997 r.

1 J. Zych, Trudna lekcja demokracji, Kraków 2005, s. 310-311. 
Po dyskusji posłowie, senatorowie, władze stronnictwa, dyrekcja i pracownicy Zakładu Historii Ruchu Ludowego, Muzeum Historii Polskiego Ruchu Ludowego, Ludowego Towarzystwa Naukowo-Kulturalnego złożyli serdeczne życzenia Jubilatowi.

\title{
Wielce Szanowny i Drogi Jubilacie! Kolego Jerzy!
}

Z okazji dostojnego Jubileuszu osiemdziesięciolecia urodzin mam zaszczyt złożyć Koledze najserdeczniejsze gratulacje w imieniu własnym oraz Zakładu Historii Ruchu Ludowego, Muzeum Historii Polskiego Ruchu Ludowego i Ludowego Towarzystwa Naukowo-Kulturalnego.

Pragnę wyrazić nasze uznanie i najwyższy szacunek dla Twojej - Dostojny Jubilacie - wieloletniej aktywności i osiągnięć w pracy społeczno-politycznej dla dobra Ojczyzny - Polski, wsi i ruchu ludowego.

W Twojej działalności w życiu społecznym i politycznym zawsze na pierwszym planie stawiałeś najszczytniejsze ideały. Byłeś wrażliwy na ludzką krzywdę i dochodzenie prawdy.

Jestem przekonany, że swym doświadczeniem nadal będziesz służył dla dobra Polski i Polaków.

Drogi Jubilacie, życzymy Ci z całego serca wszelkiej pomyślności na wiele jeszcze lat oraz dalszej wytrwałości i uporu w dążeniu do naszych wspólnych ludowych celów. Proszę, przyjmij nasze wyrazy uznania i szacunku oraz najserdeczniejsze życzenia zdrowia, pogody ducha i wszelkiej pomyślności.

\author{
Janusz Gmitruk \\ dyrektor Muzeum Historii \\ Polskiego Ruchu Ludowego
}

Niniejszy tekst został wygłoszony w Sejmie RP w dniu 8 kwietnia 2017 r. jako laudacja na jubileusz 80. rocznicy urodzin Jerzego Szymanka. 